\title{
抄 錄
}

\section{燃燒・動力・熱管理}

$620.193: 662.613 .1$

\section{灰による鋼および合金の侵ショク}

H. T. Shirley

J. Iron \& Steel. Inst., 182 (2) 144 (1956)

泥炭，重油亣き燃燒機（主としてガスタービン）の 㼛熱銅中高 $\mathrm{Ni}-\mathrm{Cr}$ 合金汶 $700 \sim 750^{\circ} \mathrm{C} て ， 1 \%$ 程度 》堛化物 (A) を念むアルカリ硫酸塩 (B) 和よびア ルカリ土類硫酸塩 $(\mathrm{C})$ によつて侵ショクされる。 Nimonic $80 \mathrm{~A}$ ( Ni $74.30 \%$, Cr $20.22 \%$ ), F. C. B. (T) 銅 (Ni 17.88\%，Cr 12.43\%) 注それぞれ（A) 之合む (B)，(C) 飞弱人, 337 銅 (N1 17.50\%, Cr $16.40 \%$, Co $7.43 \%$ ) 柱雨者に対して弱い。鋼中の $\mathrm{Cr}$ 纺 (B)の侵ショクを防ぐ効果があるが，(C)に対して は存とんど效果がない。高 $\mathrm{Ni}-\mathrm{Cr}$ 合金中の $\mathrm{Ni}$ 和よ で Cr 汶個々の場合に比べて (A), (B) 混合物に対 して弱いが，(C)に対して流い。未燃炭素があると いくらか侵ショクが稜すこと虫むるが, 侵ショクの大

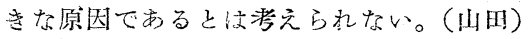

\section{固 体 然 料}

$541.6: 552.574$

\section{石炭の化学構造と性質 XIII一石炭中へのガス拡散}

P. Zwietering, J. Overeem, D. W. van Krevelen Fiel 3566 (1956)

石炭によるメタンの吸收速度空溫度 $134^{\circ} \sim 157^{\circ} \mathrm{K}$ 心て測定し次式が適用されることを示した。

$$
\nu_{s}^{t}=\frac{2 \nu_{s}{ }^{\infty} \cdot \mathrm{F} \cdot(D t)^{\mathrm{I} / 2}}{V \cdot \pi^{\mathrm{x} / 2}}
$$

ここに $\nu_{s}^{t}, \nu_{s}{ }^{\infty}$ は時間 $t=t, t=\infty$ のと等のメタン 吸收量, $F, V$ はそれぞれ石炭の比表面積, 孔隙の容

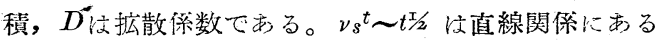
から $\nu_{s}{ }^{\circ}, F^{\prime}, V$ がわかればこの直線の倾斜からDが 求まる。Dの值汸次のと指りである。

$$
\text { 溫 度 }{ }^{\circ} \mathrm{K} \quad D \times 10^{15}, \mathrm{~cm}^{2} \mathrm{sec}^{-1}
$$

157

4.86

143

1.67

134

0.59

$D$ と溫度 $\left(\mathrm{T}^{\circ} \mathrm{K}\right)$ との間には次の関㩐があつて拡散

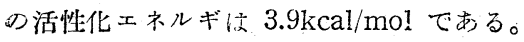

$$
D=1.2 \times 10^{-9} \exp (-3,870 / \mathrm{RT}) \mathrm{cm}^{2} \mathrm{sec}^{-1}
$$

(2) 式から $20^{\circ} \mathrm{C},-196^{\circ} \mathrm{C}$ の $D$ を求めるとそえぞ れ $1 \times 10^{-12} \mathrm{~cm}^{2} \mathrm{sec}^{-1}, 1 \times 10^{-90} \mathrm{~cm}^{2} \mathrm{sec}^{-1}$ であつてて の值を用い, $\nu_{s} t^{t}=\mathrm{r} / 2 \nu_{s} \infty$ になる時間を（1）式から計 算すると $20^{\circ} \mathrm{C}$ で纹 6 分であるが $-196^{\circ} \mathrm{C}$ で实に 1000年という大きな值になる。(川名)

\section{石炭の表面積}

$531.72: 552.574$

K. A. Kini, S. P. Nandi, J. N. Sharma, M. S. Iyengar, \& A. Lahiri Fruel 3571 (1956)

メタノールの湿潤熱をとは吸著から求められる石炭 の表面積は液体空気の溫度に扣けるアルゴンや窒素の 吸著から求めら九る BET 法の值に比して等わめて大 きいことは周知のと和りであるが著者らはメタノール の湿潤熱から石炭の表涌積学算出することが不適当で あることを示すいくつかの実験的根抛を，(1)英国産 無䐴炭心よる極性招よび無極性がスの吸著，(2) Madhya Pradesh 炭に上る極性溶媒の湿潤熱の測定, (3)低炭化度の Raniganj 炭のブリケットによるメタ ノールの湿潤熱衿よび $-183^{\circ} \mathrm{C}$ に和けるアルゴンの 吸著による $\mathrm{BET}$ 表面積の測定などの实験から得てつ ぎの結諭を下している。すなわちメタ,ノールの湿潤熱 文石炭の表面積よりはむしろ極性基の量を澌つている ようなものであるから湿潤熱の值から石炭の表面積を 算出すること文不適当である。したがつてメタノール の湿潤熱からの表面積を使つている Bangham の石炭 構造模型*は改良する必要がある。石炭構造模型とし てはある単位体が水素結合によつて結ばれているとい ら将えの方がむしる妥当である。(川名)

*D. H. Bangham et al., F'uel, 28231 (1949)

\section{乾溜・ガス化}

662.74

\section{非阽結炭より乾溜燃料の製造}

D. W. Gillings Gas 'World 143 Cok. Sec. 25 (1956)

高揮発性低品位炭より乾溜燃料を製造するためには （1）配合炭の膨脹性と凝集力の割合を適当にするこ と，(2)成型前に前処理として揮発分を除くことが必 要である。その製造工程は，(1) 洗炭 (浮選)，（2） 予備乾溜 (脫揮発)，(3) 成型，(4) 乾溜の 4 工程よ りなつている。脫揮発に流動颠溜法が行われている。 